\title{
Kerajinan Anyaman Bambu di Sanggar Kreatif "Bunga Matahari" Kelurahan Rambung Barat Kecamatan Binjai Selatan
}

\section{Woven Bamboo Crafts in "Sunflower" Creative Studio, Rambung Barat Village, South Binjai District}

\author{
Latifah Hanum Rusdi*, Heri Soeprayogi \& Mesra \\ 1)Pendidikan Seni Rupa, Fakultas Bahasa dan Seni, Universitas Negeri Medan, Indonesia \\ Diterima: 07 Juli 2020 ; Disetujui: 01 Agustus 2020 ; Dipublish: 08 Agustus 2020 \\ *Coresponding Email: latifahnum36@gmail.com
}

\begin{abstract}
Abstrak
Penelitian ini bertujuan untuk "Mengetahui Proses Pembuatan, Motif yang Diterapkan, dan Warna yang Digunakan pada Produk Kerajinan Anyaman Bambu". Metode penelitian yang dilakukan adalah metode deskriptif. Sampel yang digunakan hanya 5 jenis produk, dari setiap 5 jenis tersebut diambil 2 sampel produk. Sehingga jumlah keseluruhan sebanyak 10 sampel. Populasi pada penelitian ini berjumlah sekitar 1 jutaan produk dari 15 jenis produk yang dihasilkan. Teknik pengumpulan data menggunakan teknik observasi, wawancara, dan dokumentasi. Hasil penelitian ini menunjukkan bahwa proses pembuatan kerajinan anyaman bambu di Sanggar Kreatif "Bunga Matahari" Kelurahan Rambung Barat, Kecamatan Binjai Selatan secara garis besar memiliki 4 tahapan, yaitu penyediaan alat dan bahan, pengolahan bahan baku, proses pengerjaan, dan proses finishing. Motif yang diterapkan pada kerajinan anyaman bambu yaitu motif anyam dasar tunggal (sasaq), motif anyam dasar ganda dua (kepang), dan motif mata hero. Warna yang digunakan pada kerajinan anyaman bambu yakni warna bambu (warna alami dasar), warna merah (warna primer), warna hijau (warna sekunder), kombinasi warna merah dan hijau (warna komplementer), serta warna hitam (warna dihasilkan dari percampuran thinner dan tepung grand).
\end{abstract}

Kata Kunci: Kerajinan, Anyaman, Pembuatan, Motif, Warna.

\begin{abstract}
This research aims to "know the manufacturing process, applied motifs, and colors used in bamboo woven crafts products". The method of research done is a descriptive method. Samples are used only 5 types of products, of each 5 of these types are taken 2 samples of the product. Up to 10 total samples. The population in this study totaled about 1 million products from 15 product types produced. Data collection techniques using observation techniques, interviews, and documentation. The results of this research show that the process of making crafts woven bamboo in Sanggar creative "Sunflower" Village Rambung Barat, District South Binjai in the outline has 4 stages, namely the provision of tools and materials, processing of raw materials, process of workmanship, and finishing process. Motif applied to the handicrafts woven bamboo is a motif of a single base (sasaq), a motif of the double basic woven (braid), and hero eye motif. The color used in bamboo woven crafts are bamboo color (basic natural color), red color (primary color), green color (secondary color), a combination of red and green color (complementary color), as well as black color (the color is produced from mixing thinner and grand flour).
\end{abstract}

Keywords: Crafts, Matting, Manufacturing, Motifs, Colors.

How to Cite: Rusdi, L.H., Soeprayogi, H. \& Mesra. (2020). Kerajinan Anyaman Bambu di Sanggar Kreatif "Bunga Matahari" Kelurahan Rambung Barat Kecamatan Binjai Selatan. Journal of Education, Humaniora and Social Sciences (JEHSS). 3(1): 133-140.

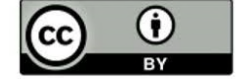




\section{PENDAHULUAN}

Dalam hal ini, untuk menghasilkan produk kerajinan anyaman bambu perlu dilakukan tahapan awal yakni pada proses pembuatannya. Berdasarkan observasi awal dan wawancara yang dilakukan pada tanggal 15 November 2019, diperoleh bahwa ada beberapa kendala yang dihadapi pengrajin didasari oleh faktor musim. Faktor ini sangat mempengaruhi proses pengeringan bambu yang telah diraut dan juga berdampak pada proses perebusan pewarnaan serat bambu yang akan dijemur hingga kering. Proses pengeringan dijemur di bawah sinar matahari langsung dan waktu yang diperlukan dalam pengeringan tergantung pada keadaan cuaca. Sehingga jika terjadi musim hujan, hal ini menjadi kendala dalam proses produksi anyaman. Sementara produksi anyaman bambu menelan waktu yang cukup lama, karena dibuat secara manual.

Dalam penerapan motif pada produk kerajinan anyam bambu di industri ini masih sederhana, cenderung menerapkan motif anyam dasar. Sisa anyaman terakhir pada pola motif juga tidak dirapikan.

Sedangkan dalam penggunaan warna, cenderung hanya pada satu atau dua warna saja. Lebih dominan-nya warna asli natural bambu menjadikan produk kerajinan anyam tersebut terlihat monoton. Selain itu, hasil pewarnaan iratan bambu dengan menggunakan bahan pewarna makanan kurang memuaskan karena warnanya cepat pudar ketika terjadi pengolahan dan tingkat keseragaman warna kurang baik serta mudah luntur bila terkena air.

Berdasarkan permasalahan diatas, maka tujuan penelitian ini adalah untuk mengetahui proses pembuatan, motif yang diterapkan, dan warna yang digunakan pada kerajinan anyaman bambu di Sanggar Kreatif "Bunga Matahari” Kelurahan Rambung Barat Kecamatan Binjai Selatan.

Pada dasarnya kerajinan merupakan kegiatan berkaitan dengan barang yang dihasilkan melalui kerajinan tangan. Kerajinan yang dibuat biasanya dari berbagai bahan, hingga menghasilkan hiasan atau benda seni maupun barang pakai (Kasnawati, 2019). Menurut Alwi (2001) dijelaskan bahwa kerajinan berasal dari kata rajin mendapat awalan ke- dan akhiran -an, dimana kerajinan disini bersifat melatih diri ke arah rajin (gerakan aktif). Sedangkan menurut Soeroto dalam Ujung dan Chairani (2018) "Seni kerajinan merupakan usaha produktif di sektor non pertanian baik untuk mata pencaharian utama maupun sampingan. Berdasarkan beberapa penjelasan di atas dapat disimpulkan bahwa kerajinan merupakan suatu kegiatan yang dihasilkan dari adanya suatu proses kerja seseorang dan sifat rajin yang mampu melahirkan sikap terampil dari tangannya, sehingga mampu menghasilkan hiasan/benda seni maupun barang pakai.

Salah satu jenis kerajinan adalah kerajinan anyaman. Margono (1997) “Anyaman merupakan salah satu karya seni yang tidak asing di Indonesia, menganyam menjadi sumber kehidupan dikalangan rakyat daerah tertentu di Negara Indonesia. Ada beberapa faktor yang menyebabkan banyaknya orang memilih bekerja sebagai pengrajin anyaman yaitu karena menganyam merupakan suatu pekerjaan yang dapat dikerjakan tanpa harus meninggalkan rumah tangga dan orang memilih menganyam untuk memanfaatkan waktu senggang (Miranda dalam Irfandi, 2018). Sedangkan menurut Garha (1986) "'Menganyam merupakan suatu kegiatan menjalin bahan yang berbentuk pita sehingga satu sama lainnya saling kuat menguatkan dan karena tekniknya, timbullah motif yang berulang. Dari beberapa pendapat di atas, dapat disimpulkan bahwa anyaman merupakan ketrampilan tangan dalam menjalin bahan yang dilakukan dengan silang menyilang dan kuat-menguatkan antara satu dengan yang lain.

Adapun bahan untuk menganyam menurut Gofur (2019) dibagi menjadi dua yaitu: (1) Bahan alam seperti bambu, rotan, eceng gondok, daun kelapa, daun lontar, dan daun pandan. (2) Bahan buatan seperti kertas dan serat plastik. Sedangkan peralatan yang digunakan dalam pembuatan kerajinan anyam bambu adalah: "pisau raut, alat pembelah bintang, pengerok bambu, pelat penyerut, tanggem (Sumiati, 1985), "bendo/arit besar, gergaji, meteran, suakan, balok dan alas papan (Margono, 1986).

Bambu sebagai bahan menganyam, dapat digunakan untuk berbagai macam keperluan lain, seperti konstruksi bangunan, meubel, dan perabot. Menurut Eratodi (2017) "Bambu mempunyai ruas dan buku, pada setiap ruas tumbuh cabang-cabang yang berukuran jauh lebih kecil dibandingkan dengan buluhnya. Ruasnya tumbuh akar-akar, sedangkan tunasnya rimpang. 急http://mahesainstitute.web.id/ojs2/index.php/jehss @ $\circlearrowleft$ mahesainstitut@gmail.com 134

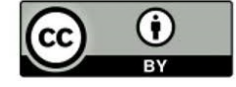

This work is licensed under a Creative Commons Attribution 4.0 
Sedangkan Haryoto (1996) menyatakan bahwa "Bambu berdaun tunggal, tersusun berselangseling diujung buluh atau ranting-rantingnya. Perakaran tanaman bambu sangat kuat, karena rimpangnya bercabang-cabang dan punya ikatan kuat yang sukar dipisahkan. Dari beberapa pengertian di atas dapat disimpulkan bahwa bambu termasuk suku rumput-rumputan yang tumbuh berumpun-rumpun dan hidup di dataran rendah maupun tinggi.

Untuk bahan kerajinan, anyaman dan perkakas pada umumnya menggunakan jenis-jenis bambu dari marga Gigantochloa dan Schizostachium (Solikin, 2004), seperti bambu gombong (gigantochloa verticillata), bambu tali/apus (gigantochloa apus), bambu talang (schizostachium brachycladum kurz) (Margono, 1986).

Dalam penelitian ini, adapun tinjauan yang dilakukan yakni pada proses pembuatan, motif dan warna dari produk kerajinan anyaman bambu. Tinjauan menurut Alwi, dkk (2003) adalah hasil meninjau, pandangan, pendapat (sesudah menyelidiki, mempelajari, dan sebagainya). Sedangkan Kamus Besar Bahasa Indonesia (2002) menjelaskan bahwa tinjauan berasal dari kata tinjau yang memiliki arti melihat, mempelajari dengan cermat, memeriksa dan menduga. Maka berdasarkan pendapat tersebut dapat disimpulkan bahwa tinjauan adalah proses pemeriksaan dalam penyelidikan terhadap peristiwa untuk menemukan masalah atau mengetahui keadaan sebenarnya.

Adapun proses pembuatan dijelaskan dalam Kamus Besar Bahasa Indonesia (1991) bahwa proses merupakan "Runtutan perubahan peristiwa dalam perkembangan sesuatu. Moeliono (1988) "Proses adalah rangkaian tindakan, pembuatan atau pengolahan yang menghasilkan produk. Pada pengertian pembuatan, Sachari (1996) menerangkan bahwa "pembuatan sebagai kegiatan yang menimbulkan tambahan manfaat atau penciptaan faedah baru yang terdiri dari faedah benda, faedah waktu, faedah tempat serta kombinasi dari faedah-faedah tersebut. Berdasarkan uraian diatas, maka dapat disimpulkan bahwa proses pembuatan adalah suatu rangkaian tindakan, pembuatan atau pengolahan suatu barang agar menimbulkan suatu manfaat baru.

Tahapan pembuatan produk kerajinan anyaman bambu ada 4 tahap yaitu penyediaan alat dan bahan, pengolahan bahan baku meliputi penebangan, pemotongan, pembelahan, pengiratan, penjemuran, pewarnaan, kemudian proses pengerjaan berupa penganyaman (Margono, 1986), dan proses finishing (Gunawan, 2008) yakni sistem vernis menggunakan copal vernish yang diaplikasikan dengan kuas, rol, dan mesin gun sprayer; sistem nitroselulosa menggunakan sanding sealer dan meuble lack; sistem melamin menggunakan melamine sanding sealer dan melamine lack.

Dalam proses menganyam, tentunya harus menerapkan motif anyam agar produk terlihat menarik dan bervariasi. Gustami (1980) menjelaskan "Motif sebagai ornamen hias adalah pangkal atau pokok dari sesuatu. Pola mengalami proses penyusunan dan ditebarkan secara berulangulang, dari proses itu akan diperoleh suatu hasil berupa pola yang dapat diterapkan pada benda lain sehingga terjadi suatu ornamen. Beberapa macam motif anyaman sebagai berikut: anyaman pasung, anyaman daun peta 1 silang, anyaman bunga cengkih, anyaman bunga cengkih besar, anyaman pihuntuan tangkup, anyaman bunga gambir, anyaman bunga lengko, anyaman ombak banyu, turih wajik, mata walik, hias jenis kelinci (Margono, 1986), tiga sumbu, empat sumbu, teratai, mata bintang, truntum (Gofur, 2019). Berdasarkan uraian diatas, dapat disimpulkan bahwa motif adalah suatu ornamen yang ditebarkan secara berulang sehingga diperoleh suatu pola yang dapat dikembangkan menjadi berbagai macam motif anyaman.

\section{METODE PENELITIAN}

Metode yang digunakan adalah metode deskriptif. Dimana peneliti tidak membuat perbandingan variabel itu pada sampel yang lain dan tidak mencari hubungan variabel itu dengan variabel yang lain (Sugiyono, 2010). Sampel yang digunakan adalah kap lampu gantung, keranjang buah, kap lampu dinding, wadah kue, wadah dimsum. Teknik pengambilan sampel menggunakan sampling jenuh. Sedangkan teknik pengumpulan data melalui observasi, wawancara, dan dokumentasi. Alat yang digunakan adalah kamera digital, catatan dan daftar pertanyaan.

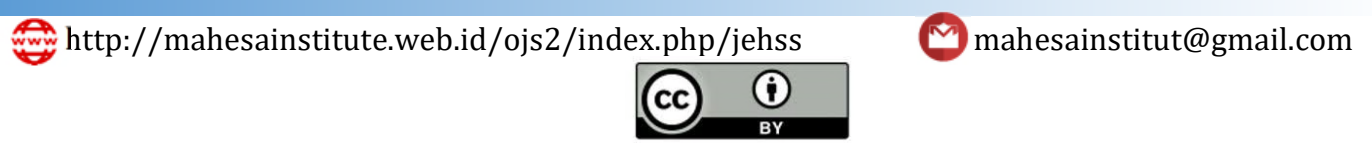




\section{HASIL DAN PEMBAHASAN}

Sanggar Kreatif "Bunga Matahari" berdiri sebagai salah satu usaha industri kerajinan anyaman bambu di Rambung Barat, Binjai Selatan pada tahun 1970 yang dikelola langsung oleh bapak Sucipto. Dan sejak tahun 2009 sampai sekarang, usaha turun temurun keluarga tersebut mulai diteruskan oleh anaknya yakni bapak Gunawan. Sebagai pengrajin anyaman, tentu hal ini merupakan suatu pekerjaan pokok yang dilakukan untuk memperoleh penghasilan. Dalam menjalankan pekerjaan, industri ini memiliki anggota sebanyak 5 orang, dan telah memiliki rumah yang dijadikan sebagai tempat gudang, sanggar pembuatan pengerjaan pesanan, tempat pelatihan, serta tempat dalam mengadakan pameran terhadap produk yang dihasilkan.

Pada mulanya pembuatan anyaman hanya menghasilkan produk seperti keranjang buah, kap lampu dan vas bunga saja. Akan tetapi, seiring perkembangan zaman dari tahun ke tahunnya industri ini mampu menghasilkan jenis produk yang bermacam-macam dan telah mengalami beberapa perubahan, diantaranya dengan mengkombinasikan berbagai macam bahan baku maupun dengan bahan kain-kain, fiber dan aksesoris lainnya sesuai kebutuhan agar menghasilkan nilai jual yang lebih tinggi. Saat ini, kurang lebih ada 15 jenis produk yang dihasilkan yakni kap lampu gantung, kap lampu duduk, kap lampu dinding, keranjang buah, kotak tissue, talam bambu, vas bunga, wadah dimsum, kipas hias, rehal, bakul, wadah kue, topi petani (caping), tampah, dan tas. Omzet yang diperoleh setiap bulan berkisar antara Rp. 6-8 juta, dimana keuntungannya sekitar $30-60 \%$.

Usaha kerajinan anyaman bambu ini merupakan salah satu sentra industri tradisional yang sifatnya rumahan. Biasanya memiliki keterbatasan dalam hal pemasaran, mulai dari keterbatasan relasi, hingga teknologi promosi yang bahkan terkadang tidak terpakai. Akan tetapi, permasalahan tersebut dapat diatasi industri ini dengan salah satu strategi yakni memperkenalkan produk melalui event-event pameran atau seminar-seminar. Selain itu juga menjalin kerja sama dengan instansi-instansi pemerintah, seperti Dinas Perindustrian dan Perdagangan, Dinas Koperasi, UKM, Dinas Sosial, dan PKK.

Seiring berjalannya waktu dalam hal pemasaran, adakala dimana masa-masa permintaan terhadap produk kerajinan anyaman bambu menjadi sunyi yaitu pada saat selesai Tahun Baru dan sesudah Lebaran. Peningkatan yang banyak terjadi pada saat mendekati Lebaran dan Tahun Baru. Untuk pemasaran produk hanya dilakukan di daerah lokal saja seperti Medan, Binjai, Tapanuli Selatan dan Pematang Siantar. Bapak Gunawan mengatakan bahwa pernah ada permintaan dari Malaysia, tetapi tidak dapat terpenuhi karena keterbatasan alat dan pengrajin sehingga tidak dapat menerima permintaan kontrak dari Malaysia tersebut.

\section{Proses Pembuatan Kerajinan Anyaman Bambu}

1. Penyediaan alat dan bahan. Untuk alat meliputi gergaji, pisau, palu, parang, tang, gunting, mesin bor, dan amplas. Untuk bahan baku yang digunakan yakni bambu belangke (Gigantochloa pruriens) dan bahan tambahan pendukung.

2. Pengolahan bahan baku yang dijalankan antara lain:

a. Proses penebangan, proses ini tidak dilakukan di Sanggar tersebut, melainkan memasok melalui supliyer bambu yang ada didaerah sekitar Kec. Binjai Selatan.

b. Proses pemotongan, menggunakan gergaji bergigi halus. Dilanjutkan dengan membersihkan kulit dengan cara mengerik secara rapi. Tujuannya untuk menghilangkan serat dan miang yang menempel pada bambu. Kemudian jemur dibawah sinar matahari selama 2 hari.

c. Proses pembelahan, dilakukan dengan cara menegakkan potongan bambu diatas permukaan datar dan keras kemudian tancapkan tegak lurus mata parang yang tajamdi tengah-tengah permukaan potongan bambu hingga terbelah.

d. Proses pengiratan, dilakukan dengan membagi belahan-belahan kecil dari hasil belahan bambu. Kemudian dibelah kembali menjadi belahan tipis yang sama besar dan pisahkan dengan membuka satu per satu dari garis belahan bagian tengah yang telah direnggangkan, demikian seterusnya. 
e. Proses penjemuran, pisahkan dan kumpulkan setiap iratan bambu, kemudian iratan dijemur agar kering dibawah sinar matahari langsung selama 1 hari. Tujuannya agar dalam proses menganyam, jalinan iratan tidak mengalami penyusutan.

f. Proses pewarnaan, basahi iratan terlebih dahulu, kemudian masukkan kedalam air mendidih yang telah diberikan pewarna makanan bubuk cap angsa, aduk selama 15 menit dan pada saat perebusan pewarnaan iratan, harus dibolak-balik agar hasil pewarnaannya merata. Lalu diangkat, dijemur dibawah sinar matahari sampai benar-benar kering dan siap untuk dianyam.

g. Proses Pengerjaan. Bahan baku yang sudah siap melalui beberapa proses pengolahan diatas dapat dikumpulkan, kemudian dianyam untuk menghasilkan berbagai bentuk motif anyaman yang sesuai dengan jenis produk yang dihasilkan.

h. Proses Finishing. Untuk memperindah produk kerajinan anyaman bambu, maka dilakukan finishing dengan cara divernish. Tujuannya agar produk tampak lebih rapi, bersih, dan mengkilap.

\section{Hasil Produk Kerajinan Bambu Sanggar Matahari}

\section{Kap Lampu Gantung}

\section{a. Produk I}

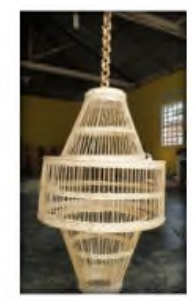

Gambar 1

(Sumber: Latifah Hanum Rusdi, Mei 2020)

Gambar 1 merupakan produk Sanggar Kreatif "Bunga Matahari". Ukuran untuk kerangka bagian atas yaitu: diameter $15 \mathrm{~cm}$ dan tinggi $25 \mathrm{~cm}$. Kerangka bagian tengah diameter $41 \mathrm{~cm}$ dan tinggi $20 \mathrm{~cm}$. Kerangka bagian bawah diameter $15 \mathrm{~cm}$ dan tinggi $25 \mathrm{~cm}$. Anyaman menggunakan motif dasar ganda dua (anyam kepang) dan motif dasar tunggal (anyam sasag). Warna yang digunakan yaitu warna alami dari bambu. Nilai alami yang dihasilkan oleh kap lampu gantung tetap terlihat.

\section{b. Produk I}

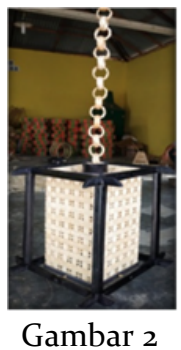

(Sumber: Latifah Hanum Rusdi, Mei 2020)

Produk kap lampu lentera gantung ini berukuran tinggi $20 \mathrm{~cm}$, panjang $25 \mathrm{~cm}$. Anyaman menggunakan motif dasar tunggal (anyam sasag). Warna yang digunakan pada motif anyaman yakni warna alami dari bambu, sedangkan warna yang digunakan untuk kerangka dasar kap lampu yakni warna hitam yang dihasilkan dari percampuran tepung grand dan thinner. 


\section{Keranjang buah}

\section{a. Produk I}

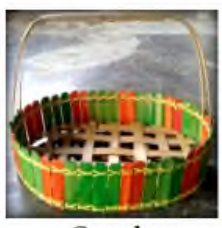

Gambar 3

(Sumber: Latifah Hanum Rusdi, Mei 2020)

Produk keranjang buah dari Sanggar Kreatif "Bunga Matahari" memiliki ukuran panjang 100 $\mathrm{cm}$, diameter $24 \mathrm{~cm}$, tinggi $30 \mathrm{~cm}$. Anyaman pada alas wadah keranjang menggunakan motif dasar tunggal (anyam sasag). Warna yang digunakan yaitu merah dan hijau, kedua warna merupakan warna komplementer yang dihasilkan dari kombinasi warna yang harmonis.

b. Produk II

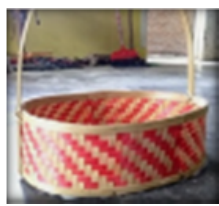

Gambar 4.

(Sumber: Latifah Hanum Rusdi, Mei 2020)

Produk keranjang buah II dengan ukuran panjang $100 \mathrm{~cm}$, diameter $24 \mathrm{~cm}$, tinggi $35 \mathrm{~cm}$. Anyaman pada alas wadah menggunakan motif anyam sasag, sedangkan pada kerangka badan keranjang menggunakan motif anyam dasar ganda dua (anyam kepang). Warna yang digunakan yakni kombinasi antar warna asli natural bambu dan warna merah.

\section{Kap lampu dinding}

\section{a. Produk I}

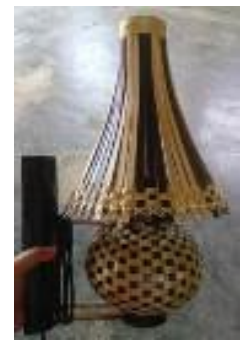

Gambar 5 .

(Sumber: Latifah Hanum Rusdi, Mei 2020)

Kap lampu dinding merupakan produk dari Sanggar Kreatif “ Bunga Matahari” dengan ukuran yaitu tinggi $35 \mathrm{~cm}$, diameter bagian atas $6 \mathrm{~cm}$, bagian tengah $9 \mathrm{~cm}$, dan bagian bawah $6 \mathrm{~cm}$. Motif anyaman yang diterapkan adalah anyam sasaq. Untuk warna yang digunakan yakni kombinasi antara hitam dan warna asli bambu.

\section{b. Produk II}

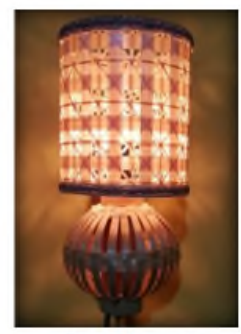

Gambar 6.

(Sumber: Latifah Hanum Rusdi, Mei 2020)

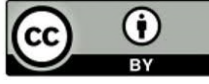


Produk II dengan ukuran tinggi $32 \mathrm{~cm}$, diameter $20 \mathrm{~cm}$. Motif anyam yang diterapkan pada badan lampu bagian bawah yakni motif dasar ganda dua (anyam kepang) dan motif dasar tunggal (anyam sasaq). Sedangkan pada badan lampu bagian atas menggunakan motif mata hero. Warna yang digunakan yakni natural bambu. Dengan demikian nilai alami yang dihasilkan kap lampu tetap terlihat.

\section{Wadah dimsum}

\section{a. Produk I}

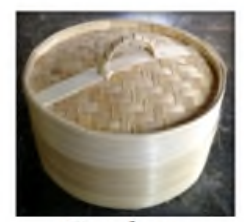

Gambar 7.

(Sumber: Latifah Hanum Rusdi, Mei 2020)

Wadah dimsum merupakan produk dari Sanggar Kreatif "Bunga Matahari”. Ukuran panjang $56 \mathrm{~cm}$, lebar $5 \mathrm{~cm}$, dengan diameter $16 \mathrm{~cm}$, dan tinggi $8 \mathrm{~cm}$. Anyaman menggunakan motif dasar ganda dua (anyam kepang). Warna yang digunakan yaitu warna asli natural bambu.

\section{Wadah kue}

\section{a. Produk I}

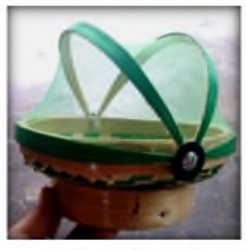

Gambar 8

(Sumber: Latifah Hanum Rusdi, Mei 2020)

Gambar 8, merupakan produk dari Sanggar Kreatif "Bunga Matahari". Ukuran panjang yaitu $50 \mathrm{~cm}$, diameter $10 \mathrm{~cm}$, tinggi $14 \mathrm{~cm}$. Anyaman menggunakan motif dasar ganda dua (anyam kepang). Warna yang digunakan yaitu warna natural bambu dan warna hijau. Penutup wadahnya menggunakan jenis kain tile biasa.

\section{SIMPULAN}

Berdasarkan hasil tinjauan dari penelitian saya tentang kerajinan anyaman bambu di Sanggar Kreatif "Bunga Matahari” Rambung Barat, Binjai Selatan ditinjau dari proses pembuatan, motif, dan warna dapat disimpulkan bahwa proses dalam pembuatan kerajinan anyaman bambu memiliki 4 tahapan, yaitu penyediaan alat dan bahan, pengolahan bahan baku, proses pengerjaan dan proses finishing. Adapun motif yang diterapkan pada kerajinan anyaman bambu yakni motif anyam dasar tunggal (sasaq), motif anyam dasar ganda dua (kepang) dan motif mata hero. Dari ketiga motif anyaman tersebut sudah bisa menciptakan berbagai macam produk kerajinan anyaman bambu. Adapun warna yang digunakan pada kerajinan anyaman bambu yakni warna bambu (warna alami dasar), warna merah (warna primer), warna hijau (warna sekunder), kombinasi warna merah dan hijau (warna komplementer), serta warna hitam (warna dari percampuran thinner dan tepung grand).

\section{DAFTAR PUSTAKA}

Alwi, H. (2001). Kamus Besar Bahasa Indonesia. Jakarta: Balai Pustaka.

Alwi, H. dkk. (2003). Tata Bahasa Buku Bahasa Indonesia. Jakarta: Balai Pustaka.

Eratodi, B. L.G.I. (2017). Struktur dan Rekayasa Bambu. Bali: Universitas Pendidikan Nasional.

Gofur, A. (2019). Ragam Teknik Anyaman. Temanggung: Desa Pustaka Indonesia.

Gunawan. (2008). Kajian Sifat-sifat Finishing Bambu Tali. Skripsi tidak diterbitkan. Bandung: Institut Pertanian Bogor.

Haryoto. (1996). Membuat Kursi Bambu. Yogyakarta: Kanisius.

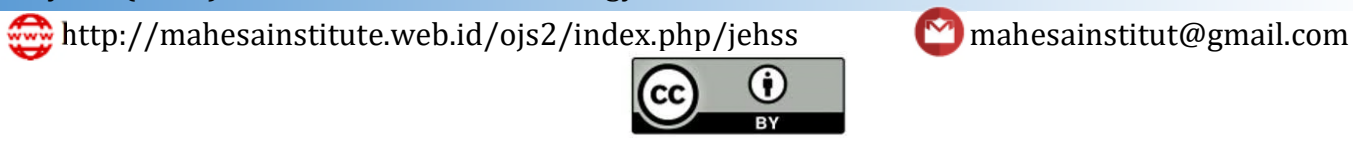


Irfandi, I., Hidayat, T., \& Azis, A. C. K. (2018). Optimalisasi Manajemen Administrasi Dan Pembukuan Keuangan Pengerajin Anyam Khas Melayu Pesisir Pantai Cermin. Prosiding Konferensi Nasional Pengabdian Kepada Masyarakat dan Corporate Social Responsibility (PKM-CSR), 1, 1610-1619

Kasmawati, K., Atmojo, W. T., Kartono, G., \& Soeprayogi, H. (2019). Pembuatan Kerajinan Keramik Dengan Teknik Pilin Pada Siswa Kelas X Smk Pelayaran Buana Bahari. Gorga: Jurnal Seni Rupa, 8(2), 392-396 Margono, G. (1986). Ketrampilan Anyaman Bambu dan Rotan. Semarang: Aneka Ilmu.

Margono, G. (1997). Keterampilan Anyaman Bambu dan Rotan. Semarang: Aneka Ilmu.

Moeliono, M.A. (1988). Kamus Besar Bahasa Indonesia. Jakarta: Balai Pustaka.

Ujung, S.C. dan Chairani. (2018). Analisis Karya Seni Kerajinan Anyam Tali Kur Siswa Kelas X Madrasah Aliyah Negeri 1 Stabat Berdasarkan Teknik Bentuk dan Warna. Gorga Jurnal Seni Rupa, 2 (1) 71-72

Solikin. (2004). Jenis-jenis Tumbuhan Suku Poaceae di Kebun Raya Purwodadi. Jurnal Biodiversitas, 16 (1) 24-26

Gustami, S.P. (1980). Nukilan Seni Ornamen Indonesia. Yogyakarta: Sekolah Tinggi Seni Rupa Indonesia (STSRI) ASRI.

Sugiyono. (2010). Metode Penelitian Kuantitatif, Kualitatif, dan R \& D. Bandung: Alfabeta.

Sumiati, U. (1985). Berkreasi Dengan Bambu 1. Bandung: Remadja Karya CV. 